\section{Africa: Journal of the International African Institute}

Published on behalf of the International African Institute

\section{Editors}

Karin Barber, University of Birmingham, UK

David Pratten, University of Oxford, UK

Africa is the premier journal devoted to the study of African societies and culture. Editorial policy encourages an interdisciplinary approach, involving humanities, social sciences, and environmental sciences.

Africa aims to give increased attention to African production of knowledge, highlighting the work of local African thinkers and writers, emerging social and cultural trends 'on the ground', and links between local and national levels of society. At the same time, it maintains its commitment to the theoretically informed analysis of the realities of Africa's own cultural categories. Each issue contains six or seven major articles, arranged thematically, extensive review essays and substantial book reviews. Special issues are published annually.

\section{Price information}

is available at: http://journals.cambridge.org/afr

\section{Free email alerts}

Keep up-to-date with new material - sign up at http://journals.cambridge.org/afr-alerts
AFRICA

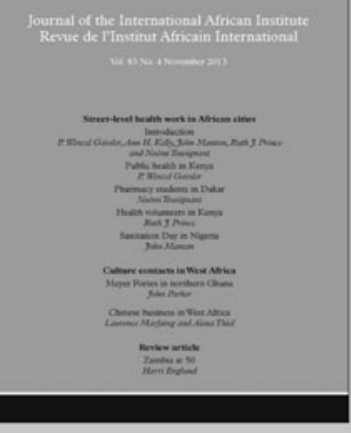

Africa: Journal of the International African Institute

is available online at:

http://journals.cambridge.org/afr

To subscribe contact

Customer Services

in Cambridge:

Phone $+44(0) 1223326070$

$\mathrm{Fax}+44(0) 1223325150$

Email journals@cambridge.org

\section{in New York:}

Phone +1 (845) 3537500

$\mathrm{Fax}+1(845) 3534141$

Email

subscriptions_newyork@cambridge.org 


\section{International}

Review of Social History

Published for the Internationaal Instituut voor Sociale Geschiedenis

\section{Executive Editor}

David Mayer, International Institute of Social History, The Netherlands

International Review of Social History is one of the leading journals in its field. Truly global in its scope, it focuses on research in social and labour history from a comparative and transnational perspective, both in the modern and in the early modern period, and across periods. The journal combines quality, depth and originality of its articles with an open eye for theoretical innovation and new insights and methods from within its field and from contiguous disciplines. Besides research articles, it features surveys of new themes and subject fields, a suggestions and debates section, review essays and book reviews.

To subscribe contact

\section{Customer Services}

\section{Americas:}

Phone +1 (845) 3537500

Fax +1 (845) 3534141

Email

subscriptions_newyork@cambridge.org

\section{Rest of world:}

Phone +44 (0)1223 326070

$\mathrm{Fax}+44(0) 1223325150$

Email journals@cambridge.org

\section{Free email alerts}

Keep up-to-date with new material - sign up at journals.cambridge.org/register 


\section{CAMBRIDGE}

\section{JOURNALS}

\section{Journal of \\ Global History}

Published for London School of Economics and Political Science

\section{Chief Editor}

William Gervase Clarence-Smith, SOAS, London, UK

\section{Editors}

Barbara Watson Andaya, University of Hawaii, USA

Merry Wiesner-Hanks, University of Wisconsin-Milwaukee, USA

Journal of Global History addresses the main problems of global change over time, together with the diverse histories of globalization. It also examines countercurrents to globalization, including those that have structured other spatial units. The journal seeks to transcend the dichotomy between 'the West and the rest', straddle traditional regional boundaries, relate material to cultural and political history, and overcome thematic fragmentation in historiography. The journal also acts as a forum for interdisciplinary conversations across a wide variety of social and natural sciences.

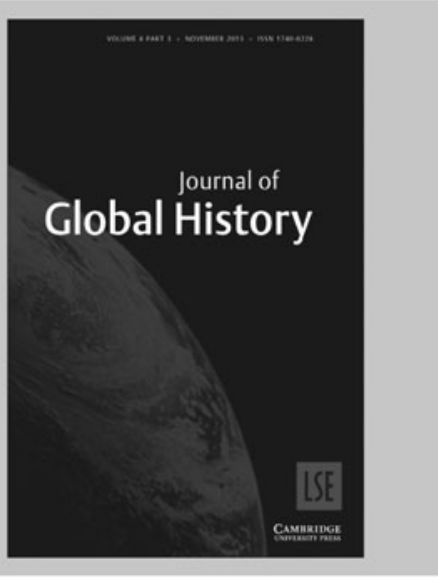

Journal of Global History

is available online at:

http://journals.cambridge.org/jgh

To subscribe contact

\section{Customer Services}

\section{Americas:}

Phone +1 (845) 3537500

$\mathrm{Fax}+1$ (845) 3534141

Email

subscriptions_newyork@cambridge.org

\section{Rest of world:}

Phone +44 (0)1223 326070

$\mathrm{Fax}+44(0) 1223325150$

Email journals@cambridge.org

\section{Free email alerts}

Keep up-to-date with new material - sign up at

journals.cambridge.org/register 
Modern

Intellectual

History

\section{Editors}

Charles Capper, Charles Capper

Duncan Kelly, University of Cambridge, UK

Anthony J. LaVopa, North Carolina State University, USA

Samuel Moyn, Columbia University, USA

This important journal serves as a focal point and forum for scholarship on intellectual and cultural history from the mid-seventeenth century to the present, with primary attention to Europe and the Americas and to transnational developments that encompass the nonWest. MIH enquires into this era's intellectual discourses and texts, their contextual origins and reception, and the recovery of their historical meanings. The journal encompasses various forms of intellectual and cultural history, including political thought and culture, philosophy, religion, literature and literary criticism, social sciences, natural sciences, visual arts and aesthetic theory, communications, law, economic thought, social and cultural theory, psychology, anthropology, music and the history of the book.

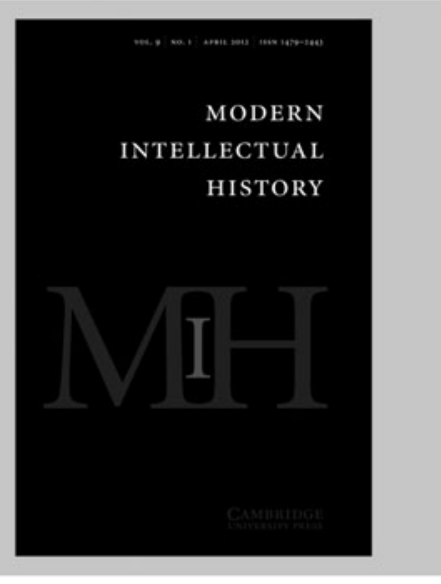

Modern Intellectual History is available online at:

http://journals.cambridge.org/mih

To subscribe contact

Customer Services

\section{Americas:}

Phone +1 (845) 3537500

Fax +1 (845) 3534141

Email

subscriptions_newyork@cambridge.org

\section{Rest of world:}

Phone +44 (0)1223 326070

$\mathrm{Fax}+44(0) 1223325150$

Email journals@cambridge.org

\section{Free email alerts}

Keep up-to-date with new material - sign up at

journals.cambridge.org/register 


\section{CAMBRIDGE}

E-books Available

for most

titles!

\section{Outstanding Scholarship from Cambridge}

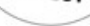

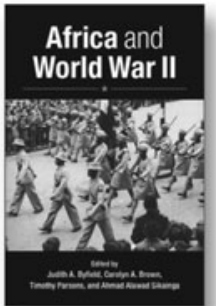

Africa and World War II*

Edited by

Judith Byfield,

Carolyn A. Brown,

Timothy Parsons, and

Ahmad Sikainga

\section{New Approaches to African History}

\section{Democracy in Africa*}

Successes, Failures, and the Struggle for Political Reform

Nic Cheeseman
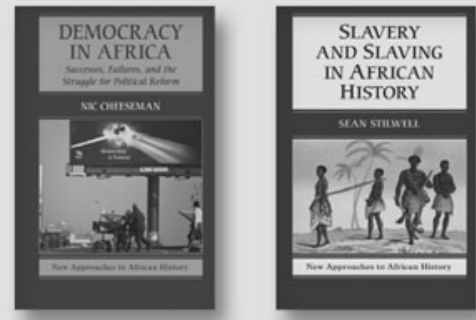

Slavery and Slaving in African History*

Sean Stilwell

\section{African History} through Sources*

Nancy J. Jacobs

*Available in paperback

Free French

Africa in

World War II*

The African Resistance

Eric T. Jennings

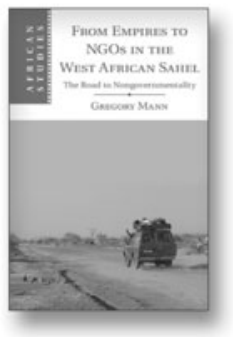

\section{From Empires to} NGOs in the West African Sahel*

The Road to

Nongovernmentality

Gregory Mann

African Studies

The Universal

Church of the Kingdom of

God in South Africa

A Church of Strangers

Ilana van Wyk

The International

African Library

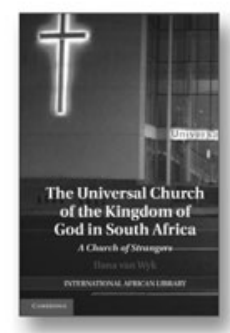

Divining Slavery and Freedom*

The Story of Domingos

Sodré, an African Priest in

Nineteenth-Century Brazil

João José Reis

Translated by

H. Sabrina Gledhill

New Approaches to the Americas

www.cambridge.org 


\section{CAMBRIDGE}

\section{JOURNALS}

\section{African Studies Review}

Published for the African Studies Association

\section{Editors}

Elliot Fratkin, Smith College, USA

Sean Redding, Amherst College, USA

Editor Emerita

Mitzi Goheen, Amherst College, USA

African Studies Review (ASR) is the principal academic and scholarly journal of the African Studies Association. ASR appears three times per year in April, September, and December, and is one of the many benefits of membership. The mission of the ASR is to publish the highest quality articles, as well as book and film reviews in all academic disciplines that are of interest to the interdisciplinary audience of ASA members.

To subscribe contact

Customer Services

\section{Americas:}

Phone +1 (845) 3537500

$\mathrm{Fax}+1(845) 3534141$

Email

subscriptions_newyork@cambridge.org

\section{Rest of world:}

Phone +44 (0)1223 326070

$\mathrm{Fax}+44(0) 1223325150$

Email journals@cambridge.org

\section{Free email alerts}

Keep up-to-date with new material - sign up at

journals.cambridge.org/asr-alerts 


\section{NOTES FOR CONTRIBUTORS}

The Journal of African History publishes research and reviews on all aspects of the African past. Contributors should keep in mind that they are writing for an academic readership generally knowledgeable about African history, and should relate their findings explicitly to relevant secondary literature.

Authors may submit contributions in either English or French. They should not exceed Io,००० words (including notes), except with prior approval of the editors. Where appropriate, carefully drawn maps, photographs, and other illustrations may accompany the text. An abstract of the contents of the article, not exceeding about soo words, should be included at the head of the main text immediately after the title.

Contributors should seek clarity, brevity, and simplicity of expression and avoid long sentences and unduly lengthy or short paragraphs. They should closely observe the conventions set out below ('Format and Style') and in the more detailed 'Instructions for Contributors' to be found as a downloadable pdf file on journal's webpage at <http://journals. cambridge.org/action/displayJournal?jid=AFH>

Article manuscripts should be submitted by email attachment to jah@cambridge.org. Soon after a manuscript is submitted, the editorial assistant will send a message acknowledging receipt. If such a message is not received within five days, please resend the message and attachment to the same address.

When a manuscript has been accepted for publication, and after typesetting, page proofs will be sent to each contributor. Corrections must be kept to a minimum: they should not include new material. Contributors should be prepared to return corrected proofs promptly. Authors of articles and review articles will receive a PDF of their article as soon as the issue in which it appears is published. They may purchase offprints provided that they order before publication on the form sent out with proofs.

\section{Format and Style}

Article manuscripts should be submitted by email attachment to jah@cambridge.org. They should be in a widely used word-processing format, preferably MS Word, and double-spaced throughout. Lines beginning new paragraphs should be indented, except at the beginning of a section. Ample margins (at least one inch left and right, one and one-half inches top and bottom) must be left, and all pages should be numbered.

Spelling (in English) may follow either British or American convention but must be consistent. African words and names should conform to the orthography of the International African Institute. In referring to people, Bantu prefixes should normally be omitted: thus 'Luganda', 'Buganda', but 'a Ganda', 'the Ganda'. Quotations of more than forty words or so should begin on a new line, indented from the left-hand margin.

Italics should be used only for the names of publications and for words in languages other than English. Foreign words should be used only when necessary, and then only with atranslation in parentheses. Figures should be used for units of measurement, percentages (to be shown in the form ' 7 per cent', not ' $7 \%$ '), and any number which includes a decimal point. Spell out other numbers up to ten and multiples of ten up to one hundred ('seven', 'twenty', but ' 25 ', 'I 27 ' and 'Io,000'). Cite dates in the form ' 12 February I968' (or 'Feb.' in sourcereferences). Express sequences in the briefest form possible ('68-9', but 'I9I I-I2', 'I 849-50').

Notes should be footnotes not endnotes. They should be numbered consecutively throughout the article and double-spaced. Citations of references should be made only in the notes and not in the text, and there should be no separate bibliography. First references should be given in full, thus: S. Johnson, The History of the Yorubas (Lagos, I92I) ; E. W. Smith, 'Sebetwane and the Makololo', African Studies, I5 (I956), 49-74. All subsequent references should be given in abbreviated form, thus: Johnson, History, 43; Smith, 'Sebetwane', 65, except that ibid. should be used to refer to an immediately preceding citation of a title. Loc. cit. and op. cit. should not be used. Do not abbreviate periodical titles. Archival citations should be as brief as is consistent with clarity. The identity and location of each archive must be fully spelled out where it is first cited.

Maps should be prepared where the topography is important for an understanding of the text. Maps should if possible be camera-ready and show all relevant information, but only such information as is mentioned in the text. Photographs should specifically enhance the text and carry full captions and attributions.

This journal issue has been printed on FSC-certified paper and cover board. FSC is an independent, non-governmental, not-for-profit organization established to promote the responsible management of the world's forests.

Printed in the United Kingdom by Bell \& Bain Ltd, Glasgow 


\section{The Journal of}

\section{AFRICAN HISTORY}

\section{CONTENTS}

\section{New Economic Histories}

The Missing People: Accounting for the Productivity of Indigenous Populations in Cape Colonial History

Johan Fourie Stellenbosch University

Erik Green Lund University

Was the Wage Burden Too Heavy? Settler Farming, Profitability, and Wage Shares of Settler Agriculture in Nyasaland, c. 1900-60

Jutta Bolt University of Groningen

Erik Green Lund University

\section{Crafting Political Identities in the Era of Decolonization}

'Entirely Christian and Entirely African': Catholic African Students in France in The Era of Independence

Elizabeth Foster Tufts University

From 'Migrants' to 'Refugees': Identity, AID, and Decolonization in Ngara District, Tanzania

\section{Jill Rosenthal Stanford University}

The Southern Problem: Representing Sudan's Southern Provinces to $c .1970$

Justin Willis Durham University

\section{Enduring Violence}

Wielding The Epokolo: Corporal Punishment and Traditional Authority in Colonial Ovamboland

David Crawford Jones The Ohio State University 30I

REVIEWS OF BOOKS 